\title{
INCIDENCE OF HPV INFECTION IN ORAL SQUAMOUS CELL CARCINOMA AND ITS ASSOCIATION WITH THE PRESENCE OF P53 \& C-MYC MUTATION : A CASE CONTROL STUDY IN MUWARDI HOSPITAL SURAKARTA
}

Adi Prayitno" ${ }^{*}$, Mandojo Rukmo², Ambar Mudigdo¹, Dalono¹, Elyana Asnar ${ }^{3}$, Retno Puji Rahayu², Joko Agus Purwanto ${ }^{4}$, Ni Nyoman Tri Puspaningsih ${ }^{5}$, Kuntoro ${ }^{6}$, Harjanto, Suhartono Taat Putra ${ }^{3}$

\author{
1. Medical School of Sebelas Maret University, Surakarta \\ 2. Dental School of Airlangga University, Surabaya \\ 3. Medical School of Airlangga University, Surabaya \\ 4. Farmacy School of Airlangga University, Surabaya; \\ 5. Mathematic and Natural Science School of Airlangga University, Surabaya \\ 6. Public Health School of Airlangga University, Surabaya \\ *Email: drgadiprayitno@yahoo.com
}

\begin{abstract}
Introduction: Annual incidence rates for oral and pharyngeal cancer are estimated at 25 cases per 100,000 in developing countries. Human papilloma virus (HPV) was implicated in pathogenesis of Cancer. The mutations of p53 and c-myc are found $50 \%$ in cancer. Objective: Aims of this research were to know the incidence of OSSC patient which realized HPV infection without p53 and c-myc gene mutation. Materials and Methods: Tissue biopsy frozen sections were taken from BOSC (Benign Oral Squamous Cell) and OSCC (Oral Squamous Cell Carcinoma) patients collected from Oral and Dental Departement of dr Muwardi Distric Hospital in Surakarta from January 2007 to January 2008. To amplify L1-HPV gene for fixed the HPV stressor. To amplify p53 and c-myc genes, continued with SSCP (Single Strand Conformational Polymorphisme) analysis and followed with measurement using densitometer, to see mutation existence. The collected data were analyzed with Chi Square. Results: BOSC patient identified 23\% with HPV infections and OSCC patient identified 73\% with HPV infections. Hundred percent BOSC patient with HPV infection without mutation in p53 gene and c-myc gene, 81\% OSCC patient with HPV infection without mutation in p53 gene and $91 \%$ OSCC patient with HPV infection without mutation in c-myc gene. Chi Square analysis showed significant difference between BOSC and OSCC patients with HPV infection without mutation in p53 and c-myc gene. Conclusion: HPV is a factor for pathogenesis of OSCC.
\end{abstract}

\begin{abstract}
Abstrak
Pendahuluan: Insidensi Infeksi HPV pada Karsinoma Sel Skuamosa Oral dan Hubungannya dengan Mutasi p53 dan c-myc: Penelitian Kasus Kontrol pada Rumah Sakit Muwardi. Rata-rata angka kejadian kanker rongga mulut dan pharyng di negara berkembang per tahun diperkirakan pada kisaran 25 kasus per 100.000 penduduk. Saat ini patogenesis kanker telah diketahui berhubungan dengan virus Human papilloma (HPV). Catatan lain bahwa mutasi pada gena $p 53$ dan $c-m y c$ ditemukan pada 50\% dari seluruh kejadian kanker. Tujuan: Tujuan penelitian ini adalah untuk mengetahui kejadian pasien Kanker Sel Skuamous Rongga Mulut (KSSRM) dengan infeksi $H P V$ tanpa mutasi gena $p 53$ dan c-myc. Bahan dan Cara: Jaringan biopsi frozen sections dari pasien Sel Skuamous Rongga Mulut Jinak (SSRMJ) dan Kanker Sel Skuamous Rongga Mulut (KSSRM) yang dikumpulkan dari Bagian Penyakit Gigi dan Mulut RSUD dr Muwardi Surakarta mulai Januari 2007 hingga Januari 2008. Amplifikasi gena L1-HPV untuk mengetahui keberadaan stressor HPV. Amplifikasi gena-gena p53 dan c-myc, dilanjutkan analisis Single Strand Comformational Polymorphisme (SSCP) dan diikuti pengukuran menggunakan densitometer untuk melihat keberadaan mutasi. Data yang terkumpul dianalisa menggunakan Uji Chi Square. Hasil: Pasien SSRMJ teridentifikasi 23\% terinfeksi $H P V$ dan pasien KSSRM teridentifikasi 73\% terinfeksi HPV. Seratus persen pasien SSRMJ yang terinfeksi HPV tercatat tanpa mutasi pada gena $p 53$ dan $c-m y c, 81 \%$ pasien KSSRM yang terinfeksi $H P V$ tercatat tanpa mutasi gena $p 53$ dan $91 \%$ pasien KSSRM yang terinfeksi HPV tercatat tanpa mutasi gena $c$-myc. Analisis uji Chi Square menunjukkan perbedaan yang signifikan antara pasien SSRMJ dan KSSRM pada infeksi $H P V$ tanpa mutasi gena $p 53$ dan $c$-myc. Kesimpulan: $H P V$ merupakan faktor untuk kejadian KSSRM.
\end{abstract}

Keywords: Developing countries; HPV; Pathogenesis; OSCC 


\section{Introduction}

Update research found that cancer is widely perceived as a heterogeneous group of disorders with different biological properties, are caused by a series of clonally selected genetic changes in tumour-suppressor genes and oncogenes. ${ }^{1,2}$ However, recent data suggest that cancer has a common basis that is grounded in a polyclonal epigenetic disruption of progenitor cells, mediated by tumour-progenitor genes. Tumour cell heterogeneity is due in part to epigenetic variation in progenitor cells and epigenetic plasticity together with genetic lesions drives tumour progression. This crucial early role for epigenetic alterations in cancer is in addition to epigenetic alterations that can substitute for genetic variation later in tumour progression. ${ }^{2,3}$ Therefore, non-neoplastic but epigenetically disrupted might be a crucial target for cancer risk management.

Cause of cancer can divide into two groups: environmental cause and hereditary genetic cause. Cancer is primarily an environmental disease, though genetics influence the risk of some cancers. Environmental factors include: environmental pollutants, diet and obesity, tobacco, infections, radiation, and lack of physical activity. These environmental factors cause or enhance abnormalities in the genetic of cells. ${ }^{3}$ The prevalence of oral cancer is increase in Africa. Annual incidence rates for oral and pharyngeal cancer are at 25 cases per 100,000 in developing countries. The urbanisation and increasing access to, and utilisation of tobacco in its various forms as well as alcohol, is to an increase in the incidence of oral cancer. ${ }^{4}$ Epidemiology of oral cancer are squamous cell represents $90 \%$ of oral cavity tumours, the incidence was increases with age (represent $3 \%$ of cancers in men and $2 \%$ of cancers in women). ${ }^{5}$ Factor that implicated as a potential cock and or promoter cancer were tobacco, alcohols, radiation of sunrise, ionization radiation, carcinogen related work, environment pollutant, medicines, nutrition and infectious agent. Another stressor is life in village, social-economic factor, age, genders and response immune mechanism. The followed factor is periodontal disease chronic, bed oral hygiene, diseases of tooth, sharp of set teeth, electrogalvanism and edentulism. Another researcher found that human papilloma virus (HPV), implicated in Oral Squamous Cell Carcinoma (OSCC) pathogenesis. ${ }^{3,6,7}$ Therefore, if the pathogenesis of OSCC can't be explained so the morbidity and mortality can increase and lead to decrease the human resources.

The role of HPV, expression of E6 and E7 protein virus, expression of $\mathrm{p} 53$ and c-myc proteins host can explained by pathobiology examination ${ }^{8,9}$ in cell perception and cell response concept. The binding of E6 protein of
HPV with p53 proteins lead to decrease the apoptosis. The other hand binding of E7 proteins with $\mathrm{pRb}$ protein lead to activate c-myc protein expression so be impact in decreases the proliferation. The mutations of p53 and c-myc are not found. ${ }^{10,11,12}$ This concept gives a chance to explain the increasing OSCC.

In the disease of high risk HPV infection explained the viral genome integrates into the host genome which is the necessary event for the keratinocytes immortality. During this process of integration the circular form of viral genome breaks at the level of the E1 and E2 regions. Different studies have shown that the integrated part of the genome corresponds to E1, E6 and E7. The loss of E2 during this process of integration produces the loss of E6 and E7 control. Therefore, the sequences E6 and E7 are directly involved in the cellular cycle by inhibiting the normal functions of $\mathrm{p} 53$ and $\mathrm{pRb}$. The $\mathrm{p} 53$ can provoke the arrest of cellular division and assure the time necessary for DNA repair. If damage can't be repaired, p53 is able to induce the apoptosis and prevent the propagation of DNA damage in subsequent generations of cells. In the case of other types of tumours, p53 is usually mutated and acts as a real oncogene. In the case of HPV infection, E6 suppresses the properties of $\mathrm{p} 53$ gene product achieving the functional equivalent of the two hits required to knock out both alleles of a tumour suppressor gene. The mutations of p53 are normally not found. The E7 protein interacts with retinoblastoma protein $(\mathrm{pRb})$, which is the crucial factor for the cellular cycle control. This interaction causes the release of the transcription factor E2F, which is now free to act and can stimulate the cellular division. E6 and E7 can cooperate with cellular oncoproteins like ras and myc which enables the virus to act at the level of growth factors and cellular and nuclear metabolism producing oncogenic cells. E6 and E7 can provoke directly DNA mutations of the host cell. This means that certain types of HPV are able to cause malignant lesions even without the action of other cofactors. ${ }^{13}$

\section{Materials and Methods}

Fourty frozen section BOSC tissue and fiveteen frozen section OSCC tissue patients collected from Oral and Dental Clinic of dr Muwardi Distric Hospital in Surakarta from January 2007 to January 2008. Parrafin blocks were made from cutting I, which was subsequently stains with Haematoxyline Eosine (HE) to ascertain the type of neoplasm.

Cutting II was subjected to Deoxyribonucleic Acid (DNA) isolation was made by Henk Schmits method with some modifications. Cut up to $25 \mathrm{mgr}$ of tissue into small pieces, place in $1.5 \mathrm{ml}$ a microfuge tube volume, and add $200 \mathrm{ul}$ of DNA extraction buffer. Add $20 \mathrm{ul}$ of Proteinase 
$\mathrm{K}$ stock solution, mix by vortexing, and incubate at $55^{\circ}$ C overnight. ${ }^{14}$

The DNA isolation results were subjected to Polymerase Chains Reaction (PCR) to amplify L1-HPV for fixed the HPV stressor. Diagnose related HPV infections are made by Henk Schmits and/or Nigel McMillan and Nina Fowler PCR-method with some modifications. ${ }^{14,15}$ Twenty five $\mu 1$ microfuge tube Ready To Go PCR Bead (Amersham Pharmacia Biotech) mixed with $2 \mu \mathrm{HPV}$ consensus

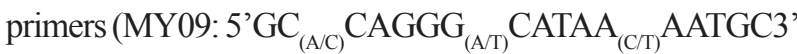
and MY11: 5' $\mathrm{CGTCC}_{(\mathrm{A} / \mathrm{C})} \mathrm{A}_{(\mathrm{A} / \mathrm{G})(\mathrm{A} / \mathrm{G})} \mathrm{GGA}_{(\mathrm{A} / \mathrm{T})}$ ACTATC3') $^{\prime}$ (CYBERGENEAB) and $2 \mu 1$ DNA template. PCR protocol for both amplifications are $94^{\circ} \mathrm{C}$ for 50 seconds, $59^{\circ} \mathrm{C}$ for 50 seconds, $72^{\circ} \mathrm{C}$ for 50 seconds and $4^{\circ} \mathrm{C}$ soak. The Amplification of HPV-L-1 gene produced $450 \mathrm{bp}$ long. Other DNA isolation results were subjected to Polymerase Chains Reaction (PCR) to amplify p53 and c-myc gene and continued Single Strand Conformational Polymorphism (SSCP) analysis and followed with measurement using densitometer to see mutation existence. To amplify of p53 and c-myc made by Henk Schmits and/or Nigel McMillan and Nina Fowler PCR-method with some modifications. ${ }^{14,15}$ Twenty five $\mu 1$ microfuge tube Ready To Go PCR Bead (Amersham Pharmacia Biotech) mixed with $2 \mu 1$ p53 primer (forward primer 5'TATCCTGAGTAGTGGTAATC3' and backward primer 3'AAGTGAATCTGAGGCATAAC') (Cybergene AB) and $2 \mu 1$ sample DNA (template). The other hand twenty five $\mu 1$ microfuge tube Ready To Go PCR Bead (Amersham Pharmacia Biotech) mixed with $2 \mu 1 \quad \mathrm{c}$-myc primer (forward primer 5'CCGTCCCTGGCTCCCCTCCTG3' and backward primer 3'GTATCGTCGCCCGCCCGTTGAAAC5') (Cybergene $\mathrm{AB}$ ) and $2 \mu \mathrm{l}$ sample DNA (template). PCR protocol for both amplifications are $94^{\circ} \mathrm{C}$ for 50 seconds, $59^{\circ} \mathrm{C}$ for 50 seconds, $72^{\circ} \mathrm{C}$ for 50 seconds and $4^{0} \mathrm{C}$ soak. The Amplification of p53 gene produced 216bp and c-myc gene produced $347 \mathrm{bp}$. Single Strand Conformational Polymorphism (SSCP) analysis followed with measurement using densitometer (Shimadzu CS 930, Dual Wave Length Cromato Scanner) to see mutation existence.

\section{Results}

The result of this research showed that nine patient from 40 patient BOSC identified have HPV infections $(9 / 40=$ $23 \%)$. Eleven patient from 15 patient OSCC identified have HPV infections $(11 / 15=73 \%)$ (Figure 1)

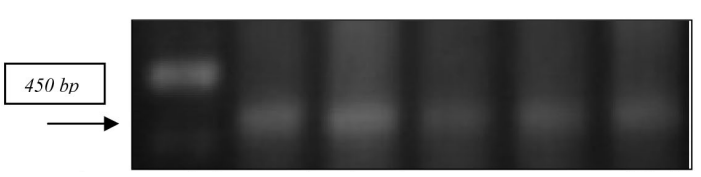

Figure 1. Polymerase Chains Reaction (PCR) L1 - HPV gene, amplified $450 \mathrm{bp}$ long.
Another result of this research showed that nine patient without mutation in p53 gene $(9 / 9=100 \%)$ and 9 patient without mutation in c-myc gene $(9 / 9=100 \%)$ after SSCP analysis that confirm by densitometer against nine patient BOSC with HPV infection. The other hand, nine patient without mutation in p53 gene $(9 / 11=81 \%)$ and 10 patient without mutation in c-myc gene $(10 / 11=91 \%)$ after SSCP analysis that confirm by densitometer against eleven patient OSCC with HPV infection (Figure 2A, 2B, 2C and Figure 3A, 3B, 3C)

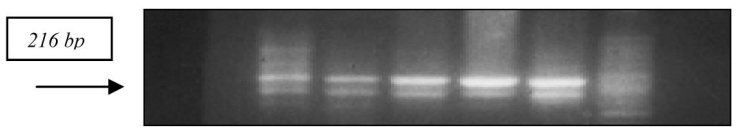

Figure 2A. Polymerase Chains Reaction (PCR) of p53 gene, amplified 216 bp long.

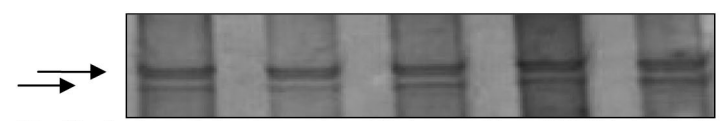

Figure 2B. Single Strand Conformational Polymorphism (SSCP) Analysis of p53 gene



Figure 2C. Measurement using densitometry to see mutation existence from Strand Conformational Polymorphism (SSCP) Analysis of p53 gene (have 2 pick - arrow)

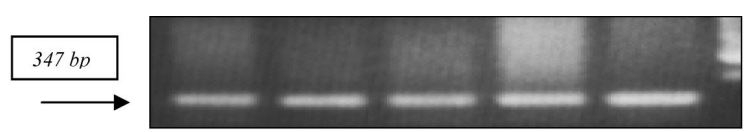

Figure 3A. Polymerase Chains Reaction (PCR) c-myc gene, amplified 347 bp long.

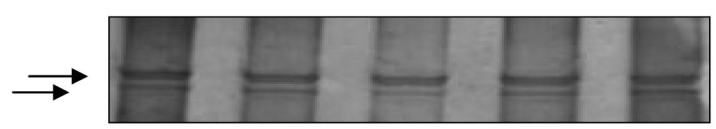

Figure 3B. Single Strand Conformational Polymorphism (SSCP) Analysis of c-myc gene 


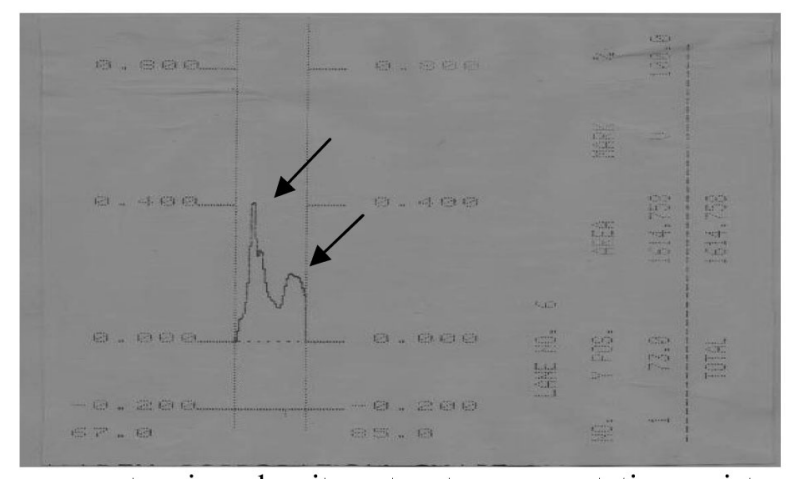

Figure 3C. Measurement using densitometry to see mutation existence from Strand Conformational Polymorphism (SSCP) Analysis of c-myc gene (have 2 pick - arrow).

Chi Square analyze showed have significant differences between BOSC and OSCC patients with HPV infection without mutation in p53 and c-myc gene (Table 1, 2, 3, 4)

Table 1. Result of the experiment in table $2 \times 2$ of p53 protein.

\begin{tabular}{lccc}
\hline & $\begin{array}{c}\text { No } \\
\text { Mutation of p53 }\end{array}$ & $\begin{array}{c}\text { Yes } \\
\text { Mutation of } \\
\mathbf{p 5 3}\end{array}$ & Total \\
\hline $\begin{array}{l}\text { OSCC with } \\
\text { HPV infection } \\
\text { BOSC with }\end{array}$ & $9(81 \%)$ & $2(19 \%)$ & 11 \\
HPV infection & $9(100 \%)$ & 0 & 9 \\
& 18 & 2 & 20 \\
\hline
\end{tabular}

Table 2. Chi Square data analysis of table 1.

\begin{tabular}{llllll}
\hline k.b & $\mathbf{O}$ & $\mathbf{E}$ & $(\mathbf{O}-\mathbf{E})$ & $(\mathbf{O}-\mathbf{E})^{\mathbf{2}}$ & $\frac{(\mathbf{O}-\mathbf{E})^{2}}{\mathbf{E}}$ \\
\hline k.1.b.1 & 9 & 9.9 & -0.9 & 0.81 & 0.08 \\
k.2.b.1 & 2 & 1.1 & 0.9 & 0.81 & 0.73 \\
k.1.b.2 & 9 & 8.1 & 0.9 & 0.81 & 0.1 \\
k.2.b.2 & 0 & 0.9 & -0.9 & 0.81 & 0.9 \\
& & & & & \\
$\mathrm{X}^{2}$ & & & & 1.81 \\
$\mathrm{X}^{\mathrm{t}}(\mathrm{df}=1 ; \mathrm{p}<0,01)$ & & & 6.63 \\
\hline
\end{tabular}

Table 3. Result of the experiment in table $2 X 2 \mathrm{of} \mathrm{cmyc}$ protein.

\begin{tabular}{lccc}
\hline & $\begin{array}{c}\text { No } \\
\text { Mutation of } \\
\text { cmyc }\end{array}$ & $\begin{array}{c}\text { Yes } \\
\text { Mutation of } \\
\text { cmyc }\end{array}$ & Total \\
\hline $\begin{array}{l}\text { OSCC with } \\
\text { HPV infection }\end{array}$ & $10(91 \%)$ & $1(19 \%)$ & 11 \\
$\begin{array}{l}\text { BOSC with } \\
\text { HPV infection }\end{array}$ & $9(100 \%)$ & 0 & 9 \\
& 19 & 1 & 20 \\
\hline
\end{tabular}

Table 4. Chi Square data analysis of table 3.

\begin{tabular}{llllll}
\hline k.b & $\mathbf{O}$ & $\mathbf{E}$ & $(\mathbf{O}-\mathbf{E})$ & $(\mathbf{O}-\mathbf{E})^{\mathbf{2}}$ & $\frac{(\mathbf{O}-\mathbf{E})^{\mathbf{2}}}{\mathbf{E}}$ \\
\hline k.1.b.1 & 10 & 10.45 & -0.45 & 0.2 & 0.01 \\
k.2.b.1 & 1 & 0.55 & 0.45 & 0.2 & 0.36 \\
k.1.b.2 & 9 & 8.55 & 0.45 & 0.2 & 0.02 \\
k.2.b.2 & 0 & 0.45 & -0.45 & 0.2 & 0.44 \\
& & & & & \\
$\mathrm{X}^{2}$ & & & & 0.83 \\
$\mathrm{X}^{\mathrm{t}}(\mathrm{df}=1 ; \mathrm{p}<0,01)$ & & & 6.63 \\
\hline
\end{tabular}

\section{Discussion}

Dental caries and periodontal disease are generally considered to be the major oral health problems around the world. In developing countries of Africa, these appear to be neither as common nor of the same order of severity as in the developed world. An epidemiological description of a given health problem usually includes its prevalence, severity (morbidity, mortality) and ageadjusted distribution in the population. Oral diseases known to exist in each community must be assessed in this way in order to develop programmes appropriate to community needs. Based on this form of analysis, the most prominent oral health problems in Africa amongst low socio-economic communities include Noma, ANUG (Acute Necrotising Ulcerative Gingivitis), oral cancer, the oral manifestations of HIV and AIDS, orofacial trauma, and dental caries. Studies have shown that the oral manifestations of HIV/AIDS are common. Candida infections, necrotizing gingivitis and oral hairy leukoplakia are the most common. The prevalence of oral cancer is also on the increase in Africa. Annual incidence rates for oral and pharyngeal cancer are estimated at 25 cases per 100,000 in developing countries. The rapid urbanisation and increasing access to, and utilisation of tobacco in its various forms as well as alcohol, is leading to. ${ }^{16}$ So the main risk factors are tobacco abuse, smokers represent $90 \%$ of oral cancer patients. Other risks that under research are viral infection like HSV and HPV. ${ }^{5,6,17,18}$ $\mathrm{P} 53$ is a gene that codes for a protein that regulates the cell cycle and hence functions as tumor suppression. It is very important for cells in multicellular organisms to suppress cancer. P53 has been described as the guardian of the genome, referring to its role in conserving stability by preventing genome mutation. The name is due to its molecular mass: it is in the 53 kilodalton fraction of cell proteins. The human p53 gene is located on the seventeenth chromosome (17p13.1). It plays an important role in cell cycle control and apoptosis. Defective p53 
could allow abnormal cells to proliferate, resulting in cancer. As many as $50 \%$ of all human tumors contain p53 mutants. ${ }^{18}$ And c-myc codes for a protein that binds to the DNA of other genes and is therefore a transcription factor. When a gene like myc is altered to cause cancer, the cancerous version of the gene is called an oncogene. The healthy version of the gene that it is derived from is called a proto-oncogene. Myc gene is located on chromosome 8 in humans and encodes for a transcription factor that is believed to regulate expression of $15 \%$ of all genes. ${ }^{19,20}$ This means that in addition to its role as a classical transcription factor. Myc also regulate global chromatin structure by regulating histone acetylation both in generich regions and at sites far from any known gene. ${ }^{21}$

\section{Conclusion}

Virus Human papilloma (HPV) is a factor for pathogenesis of Oral Squamous Cell Carcinoma (OSCC).

\section{Acknowledgments}

We thank to acknowledge Inter University Center (IUC) for Biotechnology of Gadjah Mada University Yogyakarta, Airlangga University Surabaya and Muwardi Distric Hospital Surakarta for his laboratory facilities. And Prof José Veríssimo Fernandes from Federal University of Rio Grande do Norte, Natal - Brazil for his correction and suggestion.

\section{References}

1. Samer AB, Michael AH, and Geza T. Squamous cell carcinoma of the oral tissue : A comprehensive review for oral healthcare providers. Contemp. Dent. Prac. 2005; 15:1-16.

2. Andrew PF, Rolf O, and Steven H. The epigenetic progenitor origin of human cancer. Nature Reviews Genetics. 2006; 7:21-33.

3. Kinzler, Kenneth W, Vogelstein, Bert. 'Introduction'. In The genetic basis of human cancer. Revised ed. New York: McGraw-Hill, Medical Pub. Division; 2002.

4. Elizabeth A, Tara NR, Frannie RK, Chaterine H, and Edward SP. Oral cancer knowledge, attitude and practices: A survey of dentist and primary care physicians in massachusetts. Am. Dent. Assoc. 2009; 140:461-7.

5. Cancer Research UK. Oral cancer - risk factors. http:// info.cancerresearchuk.org/cancerstats/types/oral/ riskfactors/index.htm. Cited 4/9/2009.

6. National Cancer Institute. Head and Neck Cancer. http://www.cancer.gov/cancertopics/factsheet/Sites-
Types/head-and-neck. Cited 16/05/2012.

7. Morimoto RI. Regulation of the heat shock transcriptional response: cross talk between a family of heat shock factors, molecular chaperones, and negative regulators. Genes and Dev. 1998; 12:3788-96.

8. Colin RY and Welsh CJ. Stress Health and Disease. http://www.cellscience.com/journal/journal.index.asp. Cited 26/10/2005.

9. Vogel EH, Castro ME, Solar PA and Soto FA. Enhancement of Pavlovian conditioned immunosuppression in rats. Acta Neurobiol Exp. 2007; 67:71-81.

10. Ray PK. Stress Genes and Species Survival. Moleculer and Cellular Biochemistry. Springer Netherlands. 1999; 196:117-23.

11. Putra ST. Psikoneuroimunologi. Graha Masyarakat Ilmiah Kedokteran (GRAMIK) Fakultas Kedokteran UNAIR Surabaya. 2005; p.1-15

12. Elizabeth Crown. Cell Stress Protein Linked to Breast Cancer. e-crown@northwestern.edu. Cited 2007.

13. M. A. González Intxaurraga, R. Stankovic, R. Sorli, G. Trevisan. HPV and carcinogenesis. Acta Dermatovenerologica. 2002; 11(3).

14. Schmits HL. Species Diagnostics Protocols: PCR and Other Nucleic Acid Methods. In: Clapp Humana JP, editor. Methods in Molecular Biology. Vol. 50. Press Inc., Totowa, NJ. 1996; p.109-126

15. Nigel MM, Nina F. Typing of HPV isolates by PCR: Molecular approach toward vaccine development for viral infection. Icro-Unesco Training Course, At Inter University Center for Biotecnology, Gajah Mada University, Yogyakarta, Indonesia; 1998; p.18-28.

16. Robert A. Ord, Nikolaos G. Nikitakis, and John J. Sauk. Screening the Non-High Risk Oral Cancer Patient - Part 1. http://oralcancerfoundation.org/dental/ why_screening works.htm. Cited 19/05/2012

17. WHO/AFRO. Oral Health Epidemiology. 2008.

18. Mehrotra R, Yadav S. Oral squamous cell carcinoma: Etiology, pathogenesis and prognostic value of genomic alterations. Indian Journal of Cancer. 2006; 43:60-66.

19. Read, A. P.; Strachan, T. Cancer Genetics. Human molecular genetics 2. New York: Wiley; 1999. Chept.18.

20. Anand P, Kunnumakkara AB, Kunnumakara AB. Cancer is a preventable disease that requires major lifestyle changes. Pharm. Res. 2008; 25(9):2097-116. Cotterman R, Jin VX, Krig SR, Lemen JM, Wey A, Farnham PJ, Knoepfler PS. N-Myc regulates a widespread euchromatic program in the human genome partially independent of its role as a classical transcription factor. Cancer Res. 2008; 68(23):965462. 